\title{
LANGUAGE TYPOLOGY AND RECONSTRUCTION: THE PRENASALIZED STOPS OF KISI
}

\author{
G. Tucker Childs \\ University of the Witwatersrand
}

\begin{abstract}
The findings of language typologists can contribute to understanding synchronic variation where no diachronic facts are available. By establishing what happens universally, one can extrapolate as to the past and perhaps as to the future of a language on the basis of synchronic evidence. One approach within such a framework concentrates on a typologically unusual or marked feature on the assumption that its derivation may be established from less highly marked features. This paper discusses the typologically unusual prenasalized stops of Kisi, a Mel language belonging to the Southern Branch of (West) Atlantic. The approach adopted here is based on the processoriented framework developed by Joseph Greenberg.
\end{abstract}

\section{Introduction*}

Nasality has provided phonologists with data challenging to both description and theory. Its prominence and manifest realizations attest to its pervasiveness and functional versatility. Nasality appears in nearly all languages [Maddieson 1984] and is relatively stable over time [Ohala 1974], making it a valuable focus for diachronic studies.

Nasality is, of course, important for one of the better researched features of the Atlantic languages, consonant alternation [cf. Anderson 1976]. In most Atlantic languages consonants alternate depending on phonological [Manjaku, Doneux

\footnotetext{
* The data for this paper were accumulated with the help of a Fulbright Research Grant and a Humanities Graduate Research Grant from the University of California, Berkeley. My thanks go to Kay Williamson for her comments and for making available to me several unpublished papers by John M. Stewart. Thanks also to José Tourville for sending me a copy of her paper on the reduced nasal of Manding.
} 
1969] or morphosyntactic factors [Fula, Arnott 1970]. Nasality typically characterizes at least one member of a series, often in the form of pre-nasalization. Below appears one such set of alternations from Fulfulde (Fula, Maasina dialect), showing consonants which change in noun forms. The first line shows the twoway alternations common to the voiceless consonants, and the second line shows the three-way alternations for the voiced consonants, the third member of which is a prenasalized stop.

(1) Initial consonant alternation in Fulfulde [Fagerberg-Diallo 1984:3]

$$
\begin{array}{lllll}
\text { two-way: } & f-p & s-c & h-k & \\
\text { three-way: } & w-b-m b & r-d-n d & w-g-n g & y-j-n j
\end{array}
$$

Sapir [1971] documents the full variety of consonant alternation in Atlantic.

Although it only hints at consonant alternation [Dalby 1966]), Kisi is of special interest because of the pervasiveness of nasality [Childs 1991]. Kisi has full series of both nasals and prenasalized stops, as well as progressive, anticipatory, and "spontaneous" nasalization (a situation where no nearby nasal segment is present to contribute its nasality). In addition, nasality may be used for morphological contrasts and is used expressively for emphasis. Prenasalized stops are of particular interest because of their highly marked nature and for that reason form the focus of this inquiry.

1.1. Issues and approach. The process-oriented approach of Joseph Greenberg [e.g., 1969, 1974] views functionally similar yet formally contrasting systems as representing different stages in the diachronic evolution of that system. This approach has been applied, for example, to noun class systems in general [Greenberg 1977] and to Southern Atlantic noun class markers in particular [Childs 1983].

Greenberg's approach has also been applied with good effect to prenasalized stops. Herbert [1986], for example, takes a universally marked feature, prenasalization, 1 and looks at its evolution in the languages of South America, subSaharan Africa, and Oceania, adopting Greenberg's "dynamicization of subtypologies".

In this method we take just one subtype within a typology of universal application. Such a subtype will usually be defined by the presence of a marked feature. By comparison of changes in historically independent examples, whether such changes are deduced from internal reconstruction, the comparative method, or direct historical attestation, we seek to construct a dynamic life history of the changes which such a type undergoes from its origination to its disappearance [Greenberg 1974:67].

1 Prenasalized segments can be considered marked for many reasons [Herbert 1986: 23-51], most of which are directly attributable to their often non-unitary status, that is, to their interpretation as underlying clusters. 
One caveat should be advanced before proceeding: we have to be wary of slavishly accepting a feature as marked within a language family or within an area. The feature's markedness may be based on statistical universals, whose generalizations may not hold in the smaller sphere. This may be the case with respect to nasality in languages from this part of the world. Bole-Richard [1985:5] has characterized nasality within Niger-Congo as unstable, and this instability can lead to violations of universals. For example, Stewart's [1976] reconstructed nasal vowels and postulated subsequent development in VoltaCongo violate two of Ferguson's [1963] universals. Herbert himself warns us not to use universal processes as guides to reconstruction or for claims of genetic relatedness [1986:269-70]. Nonetheless, I will claim that the facts of Kisi call for just such a treatment. In the absence of other evidence, synchronic or diachronic, typological findings serve as a starting point. Corroboration must be sought in further comparative work [Heine 1980:109], of which this discussion forms a first stage.

1.2. Course of the discussion. I first present the facts of Kisi, discussing nasality in general and prenasalized stops in particular. I then situate these facts within the framework of Herbert [1986 (especially $271 \mathrm{ff}$.)] and delineate how the prenasalized stops of Kisi might have arisen. I conclude by summarizing these findings and by indicating future directions of investigation.

\section{Nasality in Kisi}

2.1. Segmental inventory. In the following chart appear the consonants and canonical syllable structure of Kisi.

(2) Consonantal inventory

Stops

\section{Lab Alv Pal Vel Lab-Vel Glot}

$\begin{array}{llllll}\text { Nasals } & m & n & n & \eta & \eta m\end{array}$

Prenasal. $m b \quad n d \quad n j \quad \eta g \quad \eta m g b$

$\begin{array}{lllll}\text { Voiced } & b & d & & (g b)\end{array}$

$\begin{array}{llllll}\text { Voiceless } & p & t & c & k & k p\end{array}$

Fricatives

$\begin{array}{ll}f & s \\ & l\end{array}$

Liquids

Glides 
(3) Syllable structure

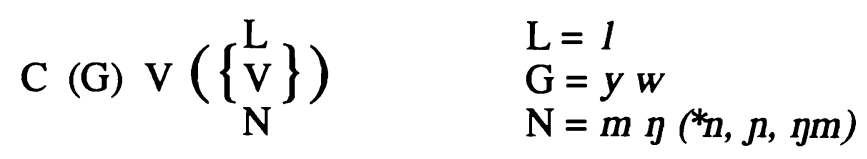

Kisi allows no consonant clusters, as shown above, and medial prenasalized stops are never ambisyllabic. In fact, no internal evidence suggests that medial prenasalized stops should be interpreted as representing more than one segment.

With regard to Kisi's prenasalized stops and voiced stops, distributional facts hint that they may once have been more closely related. An earlier system likely contained one series of stops with each phoneme having a voiced and a prenasalized allophone. 2 Synchronically, prenasalized stops are rare initially, while voiced stops are even rarer medially. Voiceless stops, on the other hand, are not restricted to initial position; they occur freely in medial position, where they contrast with prenasalized stops. The current (phonemic) prenasalized stops were, thus, once medial allophones of the voiced stops. This situation no longer obtains because the three most common prenasalized stops now appear initially and contrast with voiced stops there.

(4) Initial prenasalized stops

$\begin{array}{llll}\text { mbòmà } & \text { 'hammock' } & \text { (bòm } & \text { 'uncle') } \\ \text { ndá } & \text { 'there' } & \text { (dáàmà } & \text { 'only') } \\ \text { ngàá } & \text { 'three' } & \text { (kàà } & \text { 'taboo') }\end{array}$

When voiced stops do appear medially, they appear in the more expressive part of the lexicon, containing adverbs and ideophones, as shown in (5a). Other words with medial voiced stops are body parts or animal names transparently involving reduplication (5b). The fact that the stops appear medially via fossilized morphology underscores their rarity in medial position.

(5) Medial voiced stops 3
a. cóbé
adv. 'a little, a short time'
b. dádá
idph. 'quietly'
búbù
n. 'chin'
n. 'pig'

2 That there is no phonemic voiced velar stop in the language synchronically poses no problem for
this hypothesis. The prenasalized velar stop is related to an earlier voiced velar stop. The voicing
contrast there has been neutralized in favor of the voiceless alternant [Childs 1983]. Similar
evidence can be used to explain the presence of palatal and labialvelar prenasalized stops, despite
the lack of (phonemic) voiced stops in those places of articulation.
3 The labialvelar voiced stop gb is of extremely limited distribution and is not included in the
following discussion. In general, I focus on the more widely distributed sounds. 
Alternations between voiced and prenasalized stops also show the relatedness of the two series. For example, in rapid speech voiced stops may change to prenasalized stops [Childs 1991].

Another piece of evidence relating prenasalized stops to voiced stops is the nativization of $g$-initial words (Kisi has no (phonemic) $g$, See footnote 2). The usual pattern is for speakers to pronounce such words with an initial [k], but for some speakers, the word for 'guava' begins with a prenasalized stop.

(6) Nativization of $g$-initial words

'guava' $\rightarrow$ ngòìyàwèilén (cf. kùlàwèílén 'guava')

Further evidence supporting the hypothesis that Kisi prenasalized stops were once allophones of voiced stops comes from universal tendencies. Prenasalized stops are generally related to stops rather than to nasals [Maddieson 1984:67-68, Herbert 1986].

2.2. Nasal processes. Herbert has already established the marked nature of prenasalized stops, and the facts of Kisi support this claim, as has been demonstrated above and as will be shown below. To determine how they arose in the language, it is necessary to examine a number of different synchronic processes, all related to the spreading of nasality.

(7) Nasal processes in Kisi

Progressive nasalization of vowels and glides

Anticipatory nasalization of vowels by nin codas

Nasalization spread at morpheme boundaries

Nasal cluster reduction and place assimilation

Expressive nasalization

Progressive nasalization of vowels and glides. Nasal consonants cause following tautosyllabic vowels and glides to be nasalized.

(8) Progressive nasalization

\begin{tabular}{|c|c|}
\hline nũũ & 'my (o-class)' \\
\hline mũyyo & 'mosquito' \\
\hline nãsoo & 'scratch, write' \\
\hline ฤรีวิ & 'burned' \\
\hline
\end{tabular}

The rule has no exceptions, even nasalizing ideophones with the appropriate structural description. The process, of course, does not take place with prenasalized stops since the latter part of these sounds is oral. 
Anticipatory nasalization of vowels by $\eta$ in codas. Vowels are also nasalized before a nasal, the more expected direction for nasalization [Ruhlen 1978:223, Hombert 1986]. Herbert suggests that the process is universal: "Opposing the phonological process which nasalizes vowels after certain nasals, there is a universal phonetic process, more or less applicable in every language, which nasalizes vowels before syllable coda nasals" [1986:198]. What is unusual about Kisi is that only the velar nasal nasalizes preceding vowels, while a coda $\mathrm{m}$ does not. (Note that no other nasals appear in Kisi codas, see the display of Kisi syllable structure in (3)).

(9) Anticipatory nasalization by $\eta^{4}$ but not by $m$
a. yin
'boil'
pulũ̃
'bathe'
lẽẽ
'gecko'
b. pim

$\begin{array}{ll}\text { 'be full' } & \left({ }^{*} \text { pim }\right) \\ \text { 'burn' } & \left({ }^{*} \text { lõm }\right)\end{array}$

All of the words in (9a) have phonetically nasal vowels preceding the nasal, while those in (9b) do not.

Nasal vowels may be the source for the nasal portion of prenasalized stops. Presumably it is only the first, more general, process of progressive nasalization that is responsible. If medial voiced stops are to be prenasalized, progressive nasalization (10a) is the more likely source. Anticipatory nasalization (10b) would require an additional step deleting the conditioning element, followed by progressive nasalization.

(10) Prenasalized stops from vowel nasalization
a. NVC $\rightarrow$ NṼC $\rightarrow$ NVNC ("NC"= prenasalized stop)
b. $\mathrm{CV \eta C} \rightarrow \mathrm{C} \tilde{\mathrm{V}} \mathrm{C} \rightarrow \mathrm{CV} C \rightarrow \mathrm{CVNC}$

The second process, furthermore, is unlikely in that nasalization first spreads to the left, followed by deletion of the conditioning element, then spreads to the right, an unlikely scenario. Note the unexpected fact that vowels are nasalized only by the velar nasal; this fact will be important in establishing the actual process by which prenasalized stops arose. Other possible sources for prenasalization are discussed below.

4 Mukarovsky also notices nasalization before velar nasals, attributing it to the influence of neighboring Mande languages [1958:144]. 
The spread of nasalization at morpheme boundaries. An earlier paper [Childs 1985] discusses nasal spreading within the noun class system. The rule has greater applicability than indicated there, applying at other morphosyntactic boundaries [Childs, To appear]. Nasality in a coda (here both $\mathrm{m}$ and $\mathrm{\eta}$ ) spreads onto the onset of a following syllable, creating a prenasalized stop when the onset is filled with a liquid (11a) or glide (11b), or is empty (11c).

(11) Junctural progressive nasalization (/Onset strengthening)

a. Onsets filled with 1

$\begin{aligned} & \text { cìn } \\ & \text { tooth }\end{aligned}+\underset{\text { Suf }}{\text { Sún }} \rightarrow$ cìnndén

yìyăgndán làn $\rightarrow$ yìyăgndán ndàn 'these thoughts'

thoughts these

lè 'anymore'

ò hín [nd]è lé 'He doesn't come anymore.'

he come anymore Neg

b. Onsets filled with glides

hún wò $\rightarrow$ hún ndò

come Prt

'Come (polite)!'

cúm yá $\rightarrow$ cúm njá 'Wait for me!'

wait me

hìn $y \grave{\varepsilon} \quad \rightarrow$ hì jjè $\quad$ 'come (question)'

come $\mathrm{Q}$

c. Empty onsets (generally restricted to nominal morphology)
yìn + é $\rightarrow$ yìnndé 'hair'
hair Suf
hĕm + ó $\rightarrow$ hĕmndó 'gourd'

Here the process is transparent and synchronically active. Prenasalized stops appear when morphemes end in a nasal and following morphemes have empty onsets or begin with a glide or liquid. Nasality once again is progressive, spreading rightward. This process, then, represents a synchronically active route for the development of prenasalized stops.

Nasal cluster reduction and place assimilation. A third category of processes characterizes the homorganicity of nasal sequences, when the first 
element is the velar nasal. The velar nasal assimilates to the place of articulation of the following segment and can even disappear completely. (All of the intermediate forms in (12) are possible.)

(12) Place assimilation and nasal cluster reduction
a. $\operatorname{tu\eta }+o \rightarrow$ tunndo $\rightarrow$ tunndo $\rightarrow$ tuundo $\rightarrow$ tundo 'dog' $\operatorname{dog}$ Suf
b. $t o m+o \rightarrow$ tomndo $\rightarrow$ tomdo 'monkey'

Rarely does the velar nasal retain its place of articulation in such environments. In all stages of the example in (12a), the prenasalized stop is present. This illustrates how the conditioning environment for the appearance of a prenasalized stop may disappear and how the requisite homorganicity develops. As shown in the second example (12b), the bilabial nasal is unaffected in the same environment, although the prenasalized stop may lose its initial nasal component in rapid speech.

Expressive nasalization. Expressive nasalization may also produce pre-nasalized stops. The second person singular pronoun nùm has two emphatic forms, nùmbó and nùngó.

(13) Kisi emphatic pronouns
nùmbó hín
nùngó hín
'Did you come?'
'Did you come?'

The prenasalized element gives the word more prominence, as would be expected if it were to be emphasized. These emphatic forms may be the result of an emphatic suffix, ó, followed by the strengthening observed in (11).

This situation parallels one found in Swahili where the emphatic form of the copula $n i$ is $n d i$ (roughly speaking).

(14) Emphatic forms in Swahili5

\begin{tabular}{|c|c|c|c|}
\hline Non-emphatic & & Emphatic & \\
\hline $\begin{array}{l}\text { ni ninyi } \\
\text { Cop you (pl) }\end{array}$ & $\rightarrow$ & ndinyi & 'It is you (pl).' \\
\hline ni hao & $\rightarrow$ & ndio & 'It is they.', \\
\hline ni napa & $\rightarrow$ & nаıро & It is nere. \\
\hline
\end{tabular}

5 All examples were used by native speakers of Swahili in Malindi, Kenya. The latter two also appear as standard forms in the Swahili textbook by Hinnebusch \& Mirza [1979]. 
The same explanation of emphasis may be available for the unexpected presence of $[\mathrm{mb}]$ in the Kisi form $m b o$, representing the combination of the conjunction $\mathrm{mi}$ with the third person singular pronoun $o$. The paradigm in (15) shows that for all other persons the results are unremarkable when the conjunctions and personal pronouns combine.

(15) The conjunction mi and subject pronouns

$\begin{array}{lll} & \text { Singular } & \text { Plural } \\ \text { 1st } & m i(m i+1) & \text { mij }(m i+\eta) \\ \text { 2nd } & m a(m i+a) & \text { mila }(m i+l a) \\ \text { 3rd } & m b o(m i+o) & m a(m i+a)\end{array}$

Yet the third person singular form is not an easily analyzable combination of conjunction and pronoun, as is the case with all of the other pronouns. In that it is a prenasalized rather than a simple nasal parallels the use of prenasalization for emphasis above. In fact, the conjunction mi functions to emphasize a following clause. This secondary function thus suggests why it is the prenasalized stop, rather than the simple nasal, that appears. For example, to underscore the fact that one is really leaving one would not say, í kúè 'I'm going', or even yá í kúè 'As for me, I'm going', but rather mí kúè 'I'm going!'. (That it is only the third person with the prenasalized form may be related to the fact that the pronoun is [o], phonetically identical (on the segmental level) to the emphatic particle.) Thus, we see that expressiveness may also be a factor in the creation of prenasalized stops, albeit in a less systematic manner.

2.3. Summary and evaluation. In (16) appear four generalizations that can be made about Kisi nasalization.

(16) Kisi nasalization patterns

i. Synchronically phonemic prenasalized stops were once allophones of voiced stops in medial position.

ii. Nasality is progressive, the exception being vowel nasalization before the velar nasal, the source always being a (full) nasal.

iii. Prenasalized stops appear morpheme initially as a junctural phenomenon.

iv. Emphasis may selectively strengthen nasals to prenasalized stops.

The picture that emerges from these facts features one obscured diachronic process and three active synchronic processes, one of which runs counter to the 
progressive trend in the language. The third of these, expressive nasalization, can be discarded as unimportant because of its lack of systematicity and because it relates prenasalized stops to nasals rather than to voiced stops.

A reasonable ordering of the other facts, however, can be produced within the framework of Herbert [1986], many of whose insights have already been recalled above. According to Herbert, prenasalized stops arise in basically two ways, both of which can be identified in Kisi:

1) nasal abutment (one segment from two);

2) environmental shielding (one segment changes).

"Nasal abutment" requires that a nasal consonant be adjacent to an oral consonant, a possibility consistent with the morphosyntactic processes of Kisi outlined above, e.g., the suffixation of noun class markers to noun stems. In this scenario Kisi prenasalized stops originated in consonant clusters, a nasal followed by a voiced stop, which eventually united in single segments.

"Environmental shielding" partially protects or maintains the nasality or orality of underlying single consonantal segments. In this development pre-nasalized stops arise from single segments. For example, an oral stop after a nasal vowel becomes a prenasalized stop rather than a fully nasal stop, preserving its orality. Were it to become a fully nasal stop, there would be no contrast between nasal and non-nasal stops after nasal vowels; only nasals would appear. 6 This scenario, however, typically requires that vowel nasality be phonemic. In the case of Kisi, environmental shielding cannot be invoked because the language has no contrastive vowel nasality, despite the suggestive evidence from phonetic nasalization.

What is more suggestive is the evidence from anticipatory nasalization triggered by the velar nasal, especially in that it contrasts with the more general progressive pattern and in that $\eta$ behaves so differently from the bilabial nasal. The velar nasal alternates with $\emptyset$, while the bilabial nasal does not. 7 The bilabial nasal in Kisi codas does not nasalize vowels as does the velar nasal. As shown above in (12), unlike its velar counterpart, the bilabial nasal does not assimilate to following segments, nor does it disappear.

The velar nasal, in fact, represents formerly nasal vowels in Kisi. Earlier nasal vowels have become sequences of vowel and velar nasal, an unusual development but one that seems motivated by the facts of Kisi and by comparative data. Early French writers even transcribed nasal vowels in Kisi words (French has contrastively nasalized vowels).

\footnotetext{
6 Environmental shielding can also lead to postnasalized segments, e.g., [bm].

7 Kay Williamson [1990 p.c.] sees the persistence of [m] as further evidence for the claim that $m$ is the primary nasal consonant in Niger-Congo.
} 
(17) Anticipatory nasalization by the velar nasal

\begin{tabular}{lll} 
Phonemic & Transcribed & \\
\hline tàbíláy & tambittã [Schaeffner 1951] & 'long drums' \\
kòówán & kowã [Paulme 1954] & 'blood' \\
lèèlán & lirã $[$ [Paulme 1954] & 'horns'
\end{tabular}

Contrastive vowel nasalization is common throughout Atlantic, found in languages closely related to Kisi [Childs 1990]. In some instances the syllablefinal velar nasal even appears as a Kisi innovation. Furthermore, in nearby (unrelated) languages the velar nasal exhibits comparable behavior [Tourville 1990].

If Kisi once possessed contrastive vowel nasality, then environmental shielding is the process at work rather than nasal abutment. Abutment is responsible for prenasalized stops at morpheme boundaries but cannot account for the phonemic prenasalized stops appearing morpheme internally. Further support for shielding is found in the unitary behavior of Kisi's prenasalized stops noted previously.

On the basis of the internal facts of Kisi and the findings of Herbert, we can now posit that phonemic prenasalized stops arose to protect medial voiced stops from becoming fully nasal, i.e., the first process rather than the second in (18).

(18) The development of prenasalized stops

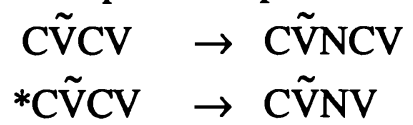

Interestingly, the loss of contrastive vowel nasalization, the original source for prenasalized stops, has led to abutment, a new source for prenasalized stops. Earlier nasal vowels are now realized as a vowel followed by a velar nasal; the velar nasal now causes prenasalization on many following segments. This analysis shows that in Kisi we have the partial linking of what Herbert sees as typologically distinct processes.

It is possible to speculate on why the velar nasal replaced nasal vowels, and the answer seems to be a functional one, to preserve the nasality registered on vowels, which had since moved rightward. If we assume bisyllabic CVCV stems, medial nasal vowels, at least when followed by a voiced segment, could lose their nasality and have it register (phonetically) on a following segment, producing a prenasalized stop. However, stem-finally there was no such recourse for the rightward migrating nasality. The result was a velar nasal, the least (perceptually) distinct of all the nasals. What precipitated this rightward movement of nasality? Perhaps it was the fact that nasality had begun spreading from preceding nasal consonants, another wave of nasality to obscure stop contrasts. It may even be that the synchronically active process of progressive nasalization in Kisi may 
already be laying the groundwork for further developments; phonetically nasal vowels may portend a new batch of prenasalized stops.

\section{Conclusion and further work}

This paper has shown that, although no direct source for the phonemic prenasalized stops of Kisi exists, synchronic evidence coupled with Herbert's findings shows how they might have arisen. What superficially seemed to be the source-abutment-turns out to be a recapitulation of an earlier process of shielding.

There are indeed limits to the validity of internal reconstruction, especially its validity at any extensive time depth [Heine 1980]. Further intensive work on related languages will reveal the validity of this paper's claims. Comparative work should prove fruitful despite the lack of relatedness among languages within Atlantic. Although these languages seldom have phonemic prenasalized stops, nasal processes are abundant.

The processes identified in Kisi may also be present in related languages. Their presence will help to guide reconstruction and, thus, further assess the internal relatedness of Atlantic, as well as Atlantic's relatedness to Niger-Congo. The diachronic picture that emerges contributes to recent work on reconstructing nasality more generally within Niger-Congo [e.g., Stewart 1976, Bole-Richard 1985, Hombert 1986, Williamson 1987]

The discussion above has also shown the usefulness of Greenberg's techniques, especially as they have been employed by Herbert with respect to prenasalized stops. While there must be some wariness at using statistical universals to guide reconstruction, the absence of other data sometimes necessitates pursuing such a course. If the hypotheses advanced above are later proven to be incorrect, at the least they will have stimulated interest in a neglected set of languages. 


\section{REFERENCES}

Anderson, Stephen R. 1976. "On the description of consonant gradation of Fula." Studies in African Linguistics 7: 93-136.

Arnott, D.W. 1970. The Nominal and Verbal Systems of Fula. Oxford: Clarendon Press.

Bole-Richard, Rémy. 1985. "Hypothèse sur la genèse de la nasalité en NigerCongo." Journal of West African Languages 15: 2-3. 3-28.

Childs, G. Tucker. 1983. "Noun class affix renewal in Southern West Atlantic." In J. Kaye, H. Koopman, D. Sportiche, \& A.Dugas (eds.), Current Approaches to African Linguistics 2, pp.17-29. Dordrecht, Holland/Cinnaminson, NJ: Foris Publications.

Childs, G. Tucker. 1990. "Nasality in Kisi and Atlantic." Paper delivered at the 21st Annual Conference on African Linguistics, University of Georgia, Athens, Georgia. April 12-14, 1990.

Childs, G. Tucker. 1991. "Nasality in Kisi." Journal of West African Languages 21: 25-36.

Childs, G. Tucker. To appear. A Kisi Reference Grammar. New York/Berlin: Mouton.

Dalby, David. 1966. "The Mel languages in the Polyglotta Africana, Part II: Bullom, Kisi, and Gola." Sierra Leone Language Review 5:139-151.

Doneux, J.L. 1969. "La langue manjaku et l'alternance consonantique à l'initiale." African Language Review 8:193-211.

Fagerberg-Diallo, Sonja. 1984. A Practical Guide and Reference Grammar to the Fulfulde of Maasina $1 \&$ 2. Jos, Nigeria: Joint Christian Ministry in West Africa.

Givón, Talmy. 1979. "Language typology in Africa: a critical review." Journal of African Languages and Linguistics 1:199-224.

Greenberg, Joseph H. 1969. "Some methods of dynamic comparison in linguistics." In J. Puhvel (ed.), Substance and Structure in Language, pp.147203. Berkeley/Los Angeles: University of California Press. 
Greenberg, Joseph H. 1974. Language Typology: a Historical and Analytic Overview. (Janua Linguarum, Series Minor, 184.) The Hague/Paris: Mouton.

Greenberg, Joseph H. 1977. "Niger-Congo noun class markers: prefixes, suffixes, both or neither." Studies in African Linguistics, supplement 7: 97-104.

Heine, Bernd. 1980. "Language typology and linguistic reconstruction: the NigerCongo case." Journal of African Languages and Linguistics 2:95-112.

Herbert, Robert K. 1986. Language Universals, Markedness Theory, and Natural Phonetic Processes. Berlin: Mouton de Gruyter.

Hinnebusch, Thomas J., and Sarah M. Mizra. 1979. Kiswahili: msingi wa kusema, kusoma na kuandika. Lanham, NY/London: University Press of America.

Hombert, Jean-Marie. 1986. "The development of nasalized vowels in the Teke language group (Bantu)." In K. Bogers, H.v.d. Hulst, and M. Mous (eds.), The Phonological Representation of Suprasegmentals, pp. 359-79. Dordrecht, Holland/Cinnaminson, NJ: Foris Publications.

Maddieson, Ian. 1984. Patterns of Sounds. Cambridge: Cambridge University Press.

Mukarovsky, Hans G. 1958. "Kisi und Bantu." Archive für Volkerkunde, XIII: 132-173.

Ohala, John J. 1974. "Experimental historical phonology." In J.M. Anderson and C. Jones (eds.), Historical Linguistics II: theory and description in phonology, pp.353-89. Amsterdam: North Holland Publishing Company.

Paulme, Denise. 1954. Les gens du riz: Kissi de Haute-Guinée française. Paris: Librare Plon.

Ruhlen, Merritt. 1978. "Nasal vowels." In J.H. Greenberg, C.A. Ferguson, and E.A. Moravcsik (eds.), Universals of Human Language 2: phonology, pp.203241. Stanford: Stanford University Press.

Sapir, J. David. 1971. "West Atlantic: an inventory of the languages, their noun class systems, and consonant alternation." In Thomas A. Sebeok (ed.), Current Trends in Linguistics 7: 45-112. Mouton.

Schaeffner, André. 1951. Les Kissi: une societé noire et ses instruments de musique. Paris: Hermann et Cie. 
Stewart, John M. 1976. "Towards Volta-Congo reconstruction" (inaugural lecture). Leiden: University Press.

Tourville, José. 1990. "On the licensing of floating nodes: the reduced nasal of Manding." Paper delivered at the 21st Annual African Linguistics Conference, University of Georgia, Athens, Georgia. April 12-14, 1990.

Williamson, Kay. 1987. "Nasality in Ijo." In David Odden (ed.), Current Approaches to African Linguistics, pp. 397-415. Dordrecht, Holland/ Cinnaminson, NJ: Foris Publications.

Department of Linguistics

University of the Witwatersrand

Johannesburg, South Africa
[Received January, 1991;

revision received February, 1993;

accepted February 20, 1993] 
